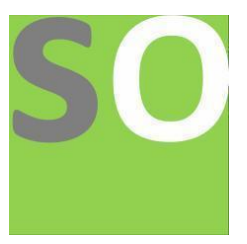

Article title: The Evaluation between Importance of Educational needs, and Satisfaction about it as perceived by Engineering students at Dire Dawa University Ethiopia

Authors: Mustefa Jibril[1]

Affiliations: Dire Dawa University, Dire Dawa, Ethiopia[1]

Orcid ids: 0000-0002-3165-2410[1]

Contact e-mail: mustefazinet1981@gmail.com

License information: This work has been published open access under Creative Commons Attribution License http://creativecommons.org/licenses/by/4.0/, which permits unrestricted use, distribution, and reproduction in any medium, provided the original work is properly cited. Conditions, terms of use and publishing policy can be found at https://www.scienceopen.com/.

Preprint statement: This article is a preprint and has not been peer-reviewed, under consideration and submitted to ScienceOpen Preprints for open peer review.

DOI: 10.14293/S2199-1006.1.SOR-.PPPCOJ7.v1

Preprint first posted online: 16 July 2021

Keywords: Educational needs, Engineering Student, Dire Dawa University 


\title{
The Evaluation between Importance of Educational needs, and Satisfaction about it as perceived by Engineering students at Dire Dawa University Ethiopia
}

\author{
Mustefa JIBRIL \\ School of Electrical \& Computer Engineering, Dire Dawa Institute of Technology, Dire Dawa, \\ Ethiopia \\ mustefa.jibril@ddu.edu.et
}

\begin{abstract}
This study aimed to examine the perception of Engineering students about importance of educational needs, and satisfaction about it. Methodology: Research design: A descriptive correlational design was used for this study. Setting: The present study was conducted at engineering faculties in Dire Dawa University. Subject: The present study included a total coverage sample includes all four academic years engineering students during academic year (2021). Total number of students was $(n=727)$. Tools of study: The study tool consisted of Engineering Education Satisfaction Instrument (EESI) consist of two questions (question one about importance of educational needs, and question 2 about satisfaction with the educational needs) contained the same items, the five subscales related to the five levels. Results: This study revealed that, there was a highly statistical significant differences among the four academic years engineering students as all fifth year engineering students had reported that the educational needs is very important, and a highly statistical significant differences among the students of the four academic years in which the second year and Third year students had the highest mean scores according to perception of the engineering students about satisfaction with the educational needs. Conclusions: there was a highly statistically significant positive relationship between perceptions of the engineering students in the four academic years about the importance of educational needs. Also observed that there was a highly statistically significant negative relationship between perceptions of the engineering students in the four academic years about the satisfaction of educational needs. Recommendations: Ask authoritative persons to improve educational environment through providing more space, and educational resources for conducting teaching learning process.
\end{abstract}

Keywords: Educational needs, Engineering Student, Dire Dawa University

\section{Introduction}

Engineering education is the activity of teaching knowledge and principles to the professional practice of engineering. It includes an initial education (bachelor's and/or master's degree), and any advanced education and specializations that follow. [1]-[4] Engineering education is typically accompanied by additional postgraduate examinations and supervised training as the requirements for a professional engineering license. The length of education, and training to qualify as a basic professional engineer, is typically 8-12 years, with 15-20 years for an engineer who takes responsibility for major projects. [5]

Science, technology, engineering, and mathematics (STEM) education in primary and secondary schools often serves as the foundation for engineering education at the university level.[6] In the 
United States, engineering education is a part of the STEM initiative in public schools.[7] Service-learning in engineering education is gaining popularity within the variety of disciplinary focuses within engineering education including chemical engineering, Civil engineering, mechanical engineering, industrial engineering, computer engineering, electrical engineering, architectural engineering, and other engineering education. [8]

A student is primarily a person enrolled in a school or other educational institution and who is under learning with goals of acquiring knowledge, developing professions and achieving employment at desired field.[7]-[9] In the broader sense, a student is anyone who applies themselves to the intensive intellectual engagement with some matter necessary to master it as part of some practical affair in which such mastery is basic or decisive.

\section{Aim of the study:}

The current study aimed to examine the perception of engineering students about importance of educational needs, and satisfaction about it.

\section{Justification of the study}

From experience of working at faculty of engineering for all academic years, the researcher observed that there are a weak relationship between students and faculty staff members \& their assistance and also interaction between students is not good. There is also inappropriate class room, insecure environment, and limited application of new technology such as smart board. All these issues may affect the educational process at faculty of engineering negatively.

So that the investigation about student's perceptions of educational needs and satisfaction is vital to the engineering profession. The outcomes of this study will provide insights into the educational needs identified by engineering students that are essential to the learning experience and satisfaction of those needs, which may contribute to student's academic success and perception of self-actualization.

This study may assist engineering educational programs in laying a stronger foundation of knowledge, competence, and confidence among its future engineers by identifying student's needs, addressing those needs and providing resources for student's success. Students' perceptions of the educational experience will contribute to a comprehensive evaluation of the engineering educational environment.

\section{Materials and Method: \\ Research design:}

A descriptive correlational research design was utilized in the present study.

\section{Setting:}

The present study was conducted at engineering faculties in Dire Dawa University.

\section{Subject:}

Subject of the present study included a total coverage sample includes all four academic years engineering students at different Faculties of Engineering in Dire Dawa University during academic years (2021). Total number of students was (727). The distributions of the four academic years were: second year (167), third year (203), fourth year (215) and fifth year (142).

\section{Tools of the study:}

\section{The study tool consisted of :}

Engineering Education Satisfaction Instrument (EESI) used to measure study subjects perception toward importance of educational needs, and satisfaction about it. Classify into two 
parts (part one about importance of educational needs, and part 2 about satisfaction with the educational needs) contained the same items, the five subscales related to the five levels.

It consists of 53 items divided into five main categories are: Basic learning Needs (BLN) 10 items, Safety and Security Needs (SSN) 11 items, Belonging to the Engineering Community Needs (BECN) 10 items, Self-confidence Needs (SCN) 11 items, and Self Actualization Needs (SAN) 11 items.

\section{Scoring system}

\section{Component of Engineering Education Satisfaction Instrument (NESI) included of:}

\section{Part 1: Importance of educational needs}

This part was rated on a 4-point likert scale from not at all necessary (Scored 1), somewhat necessary (Scored 2), moderately necessary (Scored 3), and very necessary (Scored 4). The subjects' response to each of the 53 items was summed to yield total importance scores which could range from 53 to 212 .

The student who obtain score from 1 - 53 will be considered (not at all necessary), the student who obtain score from 54 -105 will be considered (somewhat necessary), the student who obtain score from 106 - 158 will be considered (moderately necessary), and the student who obtain score from 159- 212 will be considered (very necessary).

\section{Part 2: Satisfaction with the educational needs}

This part was rated on a 4-point likert scale from not at all agreed (Scored 1), somewhat agreed (Scored 2), moderately agreed (Scored 3), and very agreed (Scored 4). The subjects' response to each of the 53 items was summed to yield total satisfaction scores which ranged from 53 to 212 .

The student who obtain score from 1 - 53 will be considered (not at all agreed), the student who obtain score from 54 -105 will be considered (somewhat agreed), the student who obtain score from 106 - 158 will be considered (moderately agreed)), and the student who obtain score from 159-212 will be considered (very agreed).

\section{Pilot study}

A pilot study was conducted for $10 \%$ of the total samples from different faculties of engineering students at Dire Dawa University. Hence, as no changes in the study sheet or obstacles in understanding the question, the pilot study included in the main study sample. Reliability of engineering education satisfaction instrument is measured by a cronbach's alpha statistical method. Reliabilities about importance of educational needs were (95.38), and Satisfaction with the educational needs were (93.75).

\section{Statistical analysis}

Data were analyzed using the statistical package for social science (SPSS) version (17), numerical data were expressed as (numbers and percentages, mean and SD), ANOVA test and chi-square test were also used. Significant is considered at $(\mathrm{p}<0.05)$.

\section{Results and Discussion}

Table (1): Frequency distribution of importance of educational needs as perceived by the undergraduate engineering students among the four academic years.

\begin{tabular}{|c|c|c|c|c|c|c|c|c|c|c|c|c|}
\hline \multirow{2}{*}{$\begin{array}{r}\text { Academic } \\
\text { years } \\
\text { Importanc }\end{array}$} & \multicolumn{2}{|c|}{$\begin{array}{l}\text { Second } \\
\text { year }\end{array}$} & \multicolumn{2}{|c|}{ Third year } & \multicolumn{2}{|c|}{$\begin{array}{l}\text { Fourth } \\
\text { year }\end{array}$} & \multicolumn{2}{|c|}{ Fifth year } & \multicolumn{2}{|c|}{ Total } & \multirow{2}{*}{\begin{tabular}{|l|}
$\mathbf{x}^{2}$ \\
69.
\end{tabular}} & \multirow{2}{*}{$\begin{array}{l}\mathbf{p} \\
0.000\end{array}$} \\
\hline & $\mathbf{N}$ & $\%$ & $\mathbf{N}$ & $\%$ & $\mathbf{N}$ & $\%$ & $\mathbf{N}$ & $\%$ & $\mathbf{N}$ & $\%$ & & \\
\hline
\end{tabular}




\begin{tabular}{|c|c|c|c|c|c|c|c|c|c|c|c|c|}
\hline $\begin{array}{l}\text { e } \\
\text { of } \\
\text { educationa } \\
\text { I needs }\end{array}$ & & & & & & & & & & & 7 & 1 \\
\hline $\begin{array}{l}\text { Moderatel } \\
\text { y necessary } \\
(\mathbf{1 0 6 - 1 5 8 )}\end{array}$ & 26 & $16 \%$ & 73 & $36 \%$ & 50 & $23 \%$ & 0 & 0 & $\begin{array}{l}14 \\
9\end{array}$ & $20 \%$ & & \\
\hline $\begin{array}{l}\text { Very } \\
\text { necessary } \\
(159-212) \\
\end{array}$ & $\begin{array}{l}14 \\
0\end{array}$ & $84 \%$ & $\begin{array}{l}13 \\
0\end{array}$ & $64 \%$ & $\begin{array}{l}16 \\
5\end{array}$ & $77 \%$ & $\begin{array}{l}14 \\
2\end{array}$ & $\begin{array}{l}100 \\
\%\end{array}$ & $\begin{array}{l}57 \\
7\end{array}$ & $80 \%$ & & \\
\hline Total & $\begin{array}{l}16 \\
7 \\
\end{array}$ & $\begin{array}{l}100 \\
\%\end{array}$ & $\begin{array}{l}20 \\
3 \\
\end{array}$ & $\begin{array}{l}100 \\
\%\end{array}$ & $\begin{array}{l}21 \\
5 \\
\end{array}$ & $\begin{array}{l}100 \\
\%\end{array}$ & $\begin{array}{l}14 \\
2 \\
\end{array}$ & $\begin{array}{l}100 \\
\%\end{array}$ & $\begin{array}{l}72 \\
7 \\
\end{array}$ & $\begin{array}{l}100 \\
\%\end{array}$ & & \\
\hline
\end{tabular}

- $\quad$ N.B (1): Not at all necessary (1-53), somewhat necessary (54-105).

- $\quad$ N.B (2): None of students reported that the not at all important of educational needs and only one student reported that somewhat important from the second year.

Table (1) showed that there was a highly statistical significant differences among the four academic years engineering students as all fifth year engineering students had reported that the educational needs is very important $(\mathrm{P}=0.0001)$.

Table (2): Mean scores of perception of the engineering students about importance of educational needs according to academic years

\begin{tabular}{|c|c|c|c|c|c|}
\hline \multirow{6}{*}{$\begin{array}{l}\text { Importance } \\
\text { educational needs }\end{array}$} & Academic years & $\mathbf{N}$ & Means \pm SD & $\mathbf{F}$ & $\mathbf{P}$ \\
\hline & Second year & 167 & $179.17 \pm 22.75$ & \multirow[t]{5}{*}{119.62} & \multirow[t]{5}{*}{0.0001} \\
\hline & Third year & 203 & $170.89 \pm 26.13$ & & \\
\hline & Fourth year & 215 & $172.76 \pm 21.09$ & & \\
\hline & Fifth year & 142 & $210.41 \pm 2.11$ & & \\
\hline & Total & 727 & $181.07 \pm 25.67$ & & \\
\hline
\end{tabular}

Table (2) revealed that there was a highly statistical significant differences among the students of the four academic years according to perception of the engineering students about importance of educational needs $(\mathrm{P}=0.0001)$. In addition the same table showed that the fifth year engineering students had the highest mean score $(210.41 \pm 2.11)$.

Table (3): Mean scores of perception of the engineering students to the five main elements about importance of educational needs according to academic years.

\begin{tabular}{|l|l|l|l|l|l|}
\hline $\begin{array}{l}\text { Importance of educational } \\
\text { needs }\end{array}$ & Academic years & $\mathbf{N}$ & Means $\mathbf{E S D}$ & $\mathbf{f}$ & $\mathbf{p}$ \\
\hline \multirow{4}{*}{ 1-Basic learning needs. } & Second year & 167 & $30.87 \pm 6.84$ & 77.4 & 0.0001 \\
\cline { 2 - 5 } & Third year & 203 & $29.34 \pm 7.57$ & & \\
\cline { 2 - 5 } & Fourth year & 215 & $31.87 \pm 6.96$ & & \\
\cline { 2 - 5 } & Fifth year & 142 & $39.55 \pm 0.95$ & & \\
\cline { 2 - 5 } & Total & 727 & $32.44 \pm 7.37$ & & \\
\hline \multirow{2}{*}{ 2-Safety and security needs } & Second year & 167 & $38.05 \pm 6.66$ & 43.14 & 0.0001 \\
\cline { 2 - 4 } & Third year & 203 & $37.24 \pm 5.80$ & & \\
\cline { 2 - 4 } & Fourth year & 215 & $36.76 \pm 7.71$ & & \\
\hline
\end{tabular}




\begin{tabular}{|c|c|c|c|c|c|}
\hline & Fifth year & 142 & $43.69 \pm 0.69$ & & \\
\hline & Total & 727 & $38.54 \pm 6.62$ & & \\
\hline \multirow{5}{*}{$\begin{array}{l}\text { 3- Belonging to the } \\
\text { engineering community and } \\
\text { love needs }\end{array}$} & Second year & 167 & $33.56 \pm 6.43$ & \multirow[t]{5}{*}{68.89} & \multirow[t]{5}{*}{0.0001} \\
\hline & Third year & 203 & $31.97 \pm 6.24$ & & \\
\hline & Fourth year & 215 & $31.62 \pm 6.26$ & & \\
\hline & Fifth year & 142 & $39.70 \pm 0.84$ & & \\
\hline & Total & 727 & $33.74 \pm 6.41$ & & \\
\hline \multirow[t]{5}{*}{ 4-Self-confidence needs } & Second year & 167 & $38.34 \pm 6.09$ & \multirow[t]{5}{*}{47.28} & \multirow[t]{5}{*}{0.0001} \\
\hline & Third year & 203 & $36.56 \pm 7.79$ & & \\
\hline & Fourth year & 215 & $36.72 \pm 5.81$ & & \\
\hline & Fifth year & 142 & $43.56 \pm 1.20$ & & \\
\hline & Total & 727 & $38.39 \pm 6.53$ & & \\
\hline \multirow[t]{5}{*}{ 5-Self-actualization needs } & Second year & 167 & $38.35 \pm 6.06$ & \multirow[t]{5}{*}{66.05} & \multirow[t]{5}{*}{0.0001} \\
\hline & Third year & 203 & $35.78 \pm 7.39$ & & \\
\hline & Fourth year & 215 & $35.79 \pm 6.30$ & & \\
\hline & Fifth year & 142 & $43.92 \pm 0.49$ & & \\
\hline & Total & 727 & $37.96 \pm 6.71$ & & \\
\hline
\end{tabular}

Table (3) clarified that there was a highly statistical significant differences among the students of the four academic years in related to perception of the engineering students about importance of educational needs $(\mathrm{P}=0.0001)$. Also in the same table indicated that the fifth year students had the highest mean scores, for the following all main elements, "basic learning needs with mean score(39.55 \pm 0.95$)$, safety and security needs with mean score (43.69 \pm 0.69$)$, belonging to the engineering community and love needs with mean score $(39.70 \pm 0.84)$, selfconfidence needs with mean score $(43.56 \pm 1.20)$, and self-actualization needs with mean score $(43.92 \pm 0.49)$ according to perception of the engineering students about importance of educational needs.

Table (4): Frequency distribution of satisfaction with the educational needs as perceived by the undergraduate engineering students among the four academic years.

\begin{tabular}{|c|c|c|c|c|c|c|c|c|c|c|c|c|}
\hline \multirow{2}{*}{$\begin{array}{l}\text { Academic } \\
\text { years } \\
\text { Satisfactio } \\
\text { n with the } \\
\text { educationa } \\
\text { I needs }\end{array}$} & \multicolumn{2}{|c|}{$\begin{array}{l}\text { Second } \\
\text { year }\end{array}$} & \multicolumn{2}{|c|}{$\begin{array}{l}\text { Third } \\
\text { year }\end{array}$} & \multicolumn{2}{|c|}{$\begin{array}{l}\text { Fourth } \\
\text { year }\end{array}$} & \multicolumn{2}{|c|}{ Fifth year } & \multicolumn{2}{|c|}{ Total } & $\mathbf{x 2}$ & p \\
\hline & $\mathbf{N}$ & $\%$ & $\mathbf{N}$ & $\%$ & $\mathbf{N}$ & $\%$ & $\mathbf{N}$ & $\%$ & $\mathbf{N}$ & $\%$ & \multirow[t]{5}{*}{$\begin{array}{l}163 . \\
3\end{array}$} & \multirow[t]{5}{*}{$\begin{array}{l}0.000 \\
1\end{array}$} \\
\hline $\begin{array}{l}\text { Somewhat } \\
\text { agreed } \\
(54-105)\end{array}$ & 51 & $\begin{array}{l}30.5 \\
\%\end{array}$ & 67 & $33 \%$ & $\begin{array}{l}18 \\
3\end{array}$ & $85 \%$ & 85 & $62 \%$ & $\begin{array}{l}38 \\
6\end{array}$ & $53 \%$ & & \\
\hline $\begin{array}{l}\text { Moderatel } \\
\text { y agreed } \\
(\mathbf{1 0 6 - 1 5 8 )}\end{array}$ & $\begin{array}{l}10 \\
9\end{array}$ & $\begin{array}{l}65.5 \\
\%\end{array}$ & $\begin{array}{l}12 \\
5\end{array}$ & $62 \%$ & 32 & $15 \%$ & 53 & $37 \%$ & $\begin{array}{l}31 \\
9\end{array}$ & $44 \%$ & & \\
\hline $\begin{array}{l}\text { Very } \\
\text { agreed } \\
(159-212)\end{array}$ & 7 & $4 \%$ & 11 & $5 \%$ & 0 & 0 & 1 & $1 \%$ & 19 & $3 \%$ & & \\
\hline Total & 16 & $100 \%$ & 20 & 100 & 21 & 100 & 14 & 100 & 72 & 100 & & \\
\hline
\end{tabular}


- N.B (1): Not at all agreed (1-53).

- N.B (2): three students reported that the not at all agreed of educational need from

Table (4) revealed that there was a highly statistical significant differences among the four academic years engineering students in which non of students from the fourth year and only one student from fifth year had very agreed as regards of their perception about satisfaction with the educational needs $(\mathrm{P}=0.0001)$.

Table (5): Mean scores of perception of the engineering students about satisfaction with the educational needs according to academic years.

\begin{tabular}{|c|c|c|c|c|c|}
\hline \multirow{6}{*}{$\begin{array}{l}\text { Satisfaction with the } \\
\text { educational needs }\end{array}$} & Academic years & $\mathbf{N}$ & Means \pm SD & $\mathbf{F}$ & $\mathbf{p}$ \\
\hline & Second year & 167 & $118.92 \pm 24.28$ & \multirow[t]{5}{*}{98.52} & \multirow[t]{5}{*}{0.0001} \\
\hline & Third year & 203 & $121.83 \pm 22.43$ & & \\
\hline & Fourth year & 215 & $91.70 \pm 14.61$ & & \\
\hline & Fifth year & 142 & $100.85 \pm 19.90$ & & \\
\hline & Total & 727 & $108.15 \pm 24.17$ & & \\
\hline
\end{tabular}

Table (5) showed that there was a highly statistical significant differences among the students of the four academic years according to perception of the engineering students about satisfaction with the educational needs $(\mathrm{P}=0.0001)$. In addition the same table indicated that the second year, and Third year students had the highest mean scores.

Table (6): Mean scores of perception of the engineering students to the five main elements about satisfaction with the educational needs according to academic years.

\begin{tabular}{|c|c|c|c|c|c|}
\hline $\begin{array}{l}\text { Satisfaction with the educational } \\
\text { needs }\end{array}$ & $\begin{array}{l}\text { Academic } \\
\text { years }\end{array}$ & $\mathbf{N}$ & Means \pm SD & $\mathbf{F}$ & $\mathbf{p}$ \\
\hline \multirow[t]{5}{*}{ 1-Basic learning needs. } & Second year & 167 & $19.21 \pm 5.56$ & \multirow[t]{5}{*}{18.32} & \multirow[t]{5}{*}{0.0001} \\
\hline & Third year & 203 & $21.73 \pm 5.14$ & & \\
\hline & Fourth year & 215 & $18.40 \pm 4.01$ & & \\
\hline & Fifth year & 142 & $19.15 \pm 4.53$ & & \\
\hline & Total & 727 & $19.66 \pm 4.99$ & & \\
\hline \multirow[t]{5}{*}{ 2-Safety and security needs } & Second year & 167 & $24.70 \pm 6.09$ & \multirow[t]{5}{*}{80.76} & \multirow[t]{5}{*}{0.0001} \\
\hline & Third year & 203 & $25.72 \pm 5.92$ & & \\
\hline & Fourth year & 215 & $18.78 \pm 4.15$ & & \\
\hline & Fifth year & 142 & $20.06 \pm 4.68$ & & \\
\hline & Total & 727 & $22.33 \pm 6.07$ & & \\
\hline \multirow{5}{*}{$\begin{array}{l}\text { 3- Belonging to the engineering } \\
\text { community and love needs }\end{array}$} & Second year & 167 & $22.75 \pm 6.27$ & \multirow[t]{5}{*}{23.14} & \multirow[t]{5}{*}{0.0001} \\
\hline & Third year & 203 & $23.15 \pm 5.89$ & & \\
\hline & Fourth year & 215 & $18.97 \pm 6.64$ & & \\
\hline & Fifth year & 142 & $19.56 \pm 5.52$ & & \\
\hline & Total & 727 & $21.12 \pm 6.41$ & & \\
\hline \multirow[t]{2}{*}{ 4-Self-confidence needs } & Second year & 167 & $25.94 \pm 7.55$ & \multirow[t]{2}{*}{127.53} & \multirow[t]{2}{*}{0.0001} \\
\hline & Third year & 203 & $25.17 \pm 5.70$ & & \\
\hline
\end{tabular}




\begin{tabular}{|c|c|c|c|c|c|}
\hline & Fourth year & 215 & $16.00 \pm 4.12$ & & \\
\hline & Fifth year & 142 & $20.46 \pm 5.48$ & & \\
\hline & Total & 727 & $21.71 \pm 7.09$ & & \\
\hline 5-Self-actualization needs & Second year & 167 & $26.32 \pm 7.70$ & 46.50 & 0.0001 \\
\hline & Third year & 203 & $26.06 \pm 6.89$ & & \\
\hline & Fourth year & 215 & $19.56 \pm 5.98$ & & \\
\hline & Fifth year & 142 & $21.62 \pm 6.77$ & & \\
\hline & Total & 727 & $23.33 \pm 7.42$ & & \\
\hline
\end{tabular}

Table (6) indicated that there was a highly statistical significant differences among the students of the four academic years in relation to perception of the engineering students about satisfaction with the educational needs $(\mathrm{P}=0.0001)$. Also the same table showed that the second year and Third year engineering students had the highest mean scores, for the following main elements, "basic learning needs with mean scores (21.73 \pm 5.14$)$ and (19.21 \pm 5.56$)$, safety and security needs with mean scores $(25.72 \pm 5.92)$ and $(24.70 \pm 6.09)$, belonging to the engineering community and love needs with mean scores (23.15 \pm 5.89$)$ and (22.75 \pm 6.27$)$, self-confidence needs with mean scores $(25.94 \pm 7.55)$ and $(25.17 \pm 5.70)$, and self-actualization needs with mean scores $(26.32 \pm 7.70)$ and $(26.06 \pm 6.89)$ in relation to perception of the engineering students about satisfaction with the educational needs".

Table (7): Relationship between perception of the nursing students in the four academic years about the importance of educational needs and their satisfaction level $(n=727)$

\begin{tabular}{|l|l|l|}
\hline \multirow{2}{*}{ Importance of educational needs } & & Academic years \\
\hline Satisfaction of educational needs & $\mathrm{r}$ & .351 \\
\cline { 2 - 3 } & $\mathrm{p}$ & 0.0001 \\
\hline & $\mathrm{r}$ & -.403 \\
\cline { 2 - 3 } & $\mathrm{p}$ & 0.0001 \\
\hline
\end{tabular}

As observed from table (7) that, there was a highly statistically significant positive relationship between perception of the engineering students in the four academic years about the importance of educational needs. Also the same table indicated that there was a highly statistically significant negative relationship between perception of the engineering students in the four academic years about the satisfaction of educational needs.

\section{Discussion}

Education is a basic right of all people and the basis for a peaceful, healthy and stable world. Also, encourages the development of an individual's total personality, traditional norms and values, and promoting understanding and development of modern science, technology, and environment conservation. Education perpetuates social, economic, and cultural prosperity of human beings and creates an infrastructure for international cooperation through the promotion of mutual understanding and tolerance, thereby enabling the achievement of self-reliant development.

Engineering faculties are continually challenged to prepare students to fulfill the role and critical competencies for professional engineering practice, and establish ways by which the achievement of these goals can be evaluated and refined to promote the integrity of the institution and advance the engineering profession. 
Therefore, this study aimed to examine the perception of engineering students about importance of educational needs, and satisfaction about it. Findings of the present study revealed the following:

In the current study, the four academic years engineering students from urban area more than engineering students from rural area (Figure 1). This result might be due to increase cost and low socioeconomic level, so they held economic view of engineering profession because it provides immediate opportunities for employment after graduation and sometimes during study which in turn lead to positive attitude of engineering students toward their future profession.

The present study, revealed that the fifthyear engineering students had the highest mean scores according to perception of the engineering students about importance of educational needs (Table 1, 2, 3). This result might be due to the fifth year engineering students become mature enough to be able to know what they needs, and which things may benefit them, the fifth year engineering students able to know basic learning needs such as effective and ineffective classroom strategies, safety and security needs such as safe and insecure of educational environment, love needs such as interaction and collaboration between faculty and students, or communicate effectively with others according to their priority and their needs easily, esteem needs such as respect between faculty and student, and self-actualization needs such as clinical sites provide learning opportunities.

As regard to the present study, revealed that the second and third years engineering students had the highest mean scores to perception of the engineering students about satisfaction with the educational needs (Table 5, 6). This result might be due to the engineering students take a lot of guidance from the demonstrators and faculty staff member which help them to more understanding.

In the current study, clarified that there was a highly statistically significant positive relationship between perception of the engineering students in the four academic years about the importance of educational needs. Also observed that there was a highly statistically significant negative relationship between perception of the engineering students in the four academic years about the satisfaction of educational needs (Table 7).

\section{Conclusion:}

In the light of the present findings it was concluded that: there was a highly statistically significant positive relationship between perceptions of the engineering students in the four academic years about the importance of educational needs. Also observed that there was a highly statistically significant negative relationship between perceptions of the engineering students in the four academic years about the satisfaction of educational needs.

\section{Recommendations:}

Based on important findings of the present study, the following recommendations were suggested:

1. Ask authoritative persons to improve educational environment through providing more space, and educational resources for conducting teaching learning process.

2. Apply law and rules for faculty members travelling to meet educational process and to increase number of faculty staff members and their assistance to meet students' needs. 
3. Provide training for the faculty staff members and their assistance about using of educational technology and innovative teaching strategy.

4. Recommend the faculty staff members at the faculties of engineering to broaden the technical setting to provide learning opportunities of engineering students.

\section{References}

[1].Shekhar, P., \& Huang-Saad, A. (2021). Examining engineering students' participation in entrepreneurship education programs: implications for practice. International Journal of STEM Education, 8(1), 1-15.

[2]. Gholaminejad, R. (2021). Disciplinary differences in the language needs of engineering students in Iran: a cross-disciplinary analysis. Journal of Applied Research in Higher Education.

[3].Tohara, A. J. T. (2021). Exploring Digital Literacy Strategies for Students with Special Educational Needs in the Digital Age. Turkish Journal of Computer and Mathematics Education (TURCOMAT), 12(9), 3345-3358.

[4].Daultani, Y., Dwivedi, A., \& Pratap, S. (2021). Benchmarking higher education institutes using data envelopment analysis: capturing perceptions of prospective engineering students. OPSEARCH, 1-17.

[5].Laamanen, M., Ladonlahti, T., Uotinen, S., Okada, A., Bañeres, D., \& Koçdar, S. (2021). Acceptability of the e-authentication in higher education studies: views of students with special educational needs and disabilities. International Journal of Educational Technology in Higher Education, 18(1), 1-17.

[6].Tilak, J. B. (2021). Students' perspectives on quality of engineering education in India. Journal of Applied Learning and Teaching, 4(1).

[7].Kramarenko, T., Bondar, K., \& Shestopalova, O. (2021, March). The ICT usage in teaching mathematics to students with special educational needs. In Journal of Physics: Conference Series (Vol. 1840, No. 1, p. 012009). IOP Publishing.

[8].Chidthachack, S., Schulte, M. A., Ntow, F. D., Lin, J. L., \& Moore, T. J. (2021, March). Engineering Students Learn ABET Professional Skills: A Comparative Study of ProjectBased-Learning (PBL) versus Traditional Students. In 2013 North Midwest Section Meeting.

[9].Prayoga, A., Irwansyah, D., \& Harya, T. D. (2021). Developing English learning materials for computer network engineering students at peripheral Indonesia. EduLite: Journal of English Education, Literature and Culture, 6(1), 28-41. 